\title{
Female sexual dysfunction amongst rural postmenopausal woman
}

\author{
Anjanadevi S. Santpure ${ }^{1 *}$, Swati N. Nagapurkar ${ }^{1}$, Purushottam A. Giri ${ }^{2}$, Prasad L. Bhanap ${ }^{1}$ \\ ${ }^{1}$ Department of Obstetrics and Gynecology, Indian Institute of Medical Science and Research Medical College, \\ Badnpapur, Jalna, Maharashtra, India \\ ${ }^{2}$ Department of Community Medicine, Indian Institute of Medical Science and Research Medical College, Badnpapur, \\ Jalna, Maharashtra, India
}

Received: 07 October 2016

Accepted: 03 November 2016

\section{*Correspondence:}

Dr. Anjanadevi S. Santpure,

E-mail: anjanasantpure@yahoo.com

Copyright: (c) the author(s), publisher and licensee Medip Academy. This is an open-access article distributed under the terms of the Creative Commons Attribution Non-Commercial License, which permits unrestricted non-commercial use, distribution, and reproduction in any medium, provided the original work is properly cited.

\section{ABSTRACT}

Background: Female Sexual dysfunction is a common neglected symptom of postmenopausal women in rural India. Prevalence of sexual dysfunction increases with age and sexual response is dynamic process influenced by sociocultural, physiological, psychological and socio-economical factors. The objective of the study was to analyse the prevalence of female sexual dysfunctions in postmenopausal women from rural area and to analyze prevalence of sexual activity among them.

Methods: A cross-sectional study was conducted from June 2015 to January 2016 in Obstetrics and Gynecology outpatient department of Indian Institute of Medical Science and Research, Badnapur, Jalna, Maharashtra which is a tertiary care centre. All postmenopausal women who have attained menopause naturally were questioned about sexual symptoms with the help of pre-tested questionnaires and then analyzed with appropriate tests.

Results: Mean age of menopause was $47.59 \pm 3.98$ yrs and $51.9 \%$ were sexually active. Mean age among sexual active and sexual inactive women was $54.42 \pm 5.23$ and $62.13 \pm 6.39$ respectively. Prevalence of dyspareunia, vaginal dryness and decreased libido were $10.7 \%, 10.7 \%$ and $55.36 \%$ respectively in sexually active postmenopausal women. Sexual activity decreased from $54.4 \%$ to $5.6 \%$ as the duration of menopause increased from 5 years or less to 11 or more years. Sexual dysfunction increased as the duration of menopause increased.

Conclusions: Sexual dysfunction is common in postmenopausal women and increases with increasing duration of menopause. Awareness of health care facility among rural menopausal women should be increased to improve their quality of life.

Keywords: Postmenopausal woman, Rural India, Sexual activity, Female sexual dysfunction

\section{INTRODUCTION}

Menopause is that point in time when permanent cessation of menstruation occurs following the loss of ovarian activity. The average age of Indian women is 68 years and is expected to increase to 73 years by 2021 and the age of menopause is $48 \pm 2$ years and hence women has to spend $1 / 3$ of her life in menopausal period. ${ }^{1}$ During menopause, women experience vasomotor, urogenital, psychosomatic and Psychological symptoms, as well as sexual dysfunction. Historically, several classification systems have been proposed for sexual dysfunction. For several decades, two most widely used classification system for sexual dysfunction have been International classification of disease (ICD)-10 provided by World Health Organisation and Diagnostic and statistical manual of mental disease (DSM)-IV provided by the American psychiatric Association. The most major categories of dysfunction in both systems are desire, arousal, orgasmic and sexual pain disorder. According to ICD-10 Classification lack or loss of sexual desire F52.0 and dyspareunia F52.6 have been included. ${ }^{2}$ Prevalence 
of female sexual dysfunction increases with age, with nearly three quarters of women older than 60 years reporting sexual inactivity and dyspareunia. ${ }^{3}$

It is very common to observe a lack of mental arousal and decline in sexual desire after a history of sexual pain. These factors may negatively influence sexual motivation, activity and couple's relationship. Thereafter, it is crucial to avoid such a cascade of negative events by treating sexual problems during menopause. ${ }^{4}$ Estrogen receptors $\alpha \& \beta$ are expressed throughout the squamous epithelium, connective tissue and smooth muscles of the vulva, vagina, urethra, and bladder trigone and are critical for mediating numerous biochemical and physiologic function during a women's reproductive years. ${ }^{5,6} \mathrm{With}$ the declining estrogen levels, vaginal secretions, transudate from the surrounding blood vessels decreases. Diminished vaginal secretions and the delay in the timing of lubrication during sexual intercourse contribute to dyspareunia in postmenopausal women. ${ }^{7}$

Before menopause, the ovaries, as well as the adrenals, produce about $50 \%$ of the circulatory testosterone and the rest is from the peripheral conversion of precursors derived from the ovary and the adrenals. After menopause, peripheral conversion of androstenedione becomes the major source of circulatory testosterone. ${ }^{8}$ Estrogen deficiency also leads to shortening and narrowing of vagina and thinning of vaginal wall .These changes leads to dryness and dyspareunia. ${ }^{9}$ Decreased testosterone levels in the menopausal women are associated with a loss of sexual desire and sexual pleasure, feeling of diminished physical wellbeing and persistent fatigue. ${ }^{10}$ As a consequence of endocrine changes, female sexual dysfunction in menopausal women is prevalent. The most common complaints in post-menopausal women are vaginal dryness, dyspareunia, low sexual desire and poor sexual satisfaction. ${ }^{7}$ With the fact that lacunae exist in this area of research, the current study was undertaken to assess the prevalence of female sexual dysfunction among postmenopausal rural women.

\section{METHODS}

A cross-sectional study was carried out from June 2015 to January 2016 in Obstetrics and Gynecology (OBGY) outpatient department of teaching hospital of Indian Institute of Medical Science and Research Medical College, Badnapur, Jalna, Maharashtra. The study included the informed consent procedure approved by research and ethical committee of the institution. A total of 520 postmenopausal women who were attended OPD during the study period were enrolled for the study.

All the postmenopausal women who have attained menopause naturally and were still in wed-lock were included in the study. Women with surgical menopause, widows, patients on hormone replacement therapy and phytoestrogens were excluded from the study.
A semi-structured and pre-tested questionnaire was used to collect the data after explaining to the participants in their own language. Postmenopausal women were asked if they had engaged in any sexual activity with their partner in the prior six months, women who answered 'yes' were considered as sexually active. These subjects were interviewed in detail to identify the various female sexual dysfunction like dyspareunia, vaginal dryness and decreased libido. These patients were also questioned about their coital frequency.

The data was analyzed by computer software MS Excel and statistical package for the social science SPSS version 17.0. Menopausal symptoms and sexual activity were calculated as percentages.

\section{RESULTS}

Table 1: Socio-demographic characteristics of the study population.

\begin{tabular}{|c|c|c|}
\hline $\begin{array}{l}\text { Socio- } \\
\text { demographic } \\
\text { characteristics }\end{array}$ & $\begin{array}{l}\text { Frequency } \\
(n=520)\end{array}$ & Percentage \\
\hline \multicolumn{3}{|c|}{ Age (in yrs) Mean Age - $55.03 \pm 6.33$} \\
\hline $46-50$ & 195 & 37.50 \\
\hline $51-55$ & 65 & 12.50 \\
\hline $56-60$ & 139 & 26.73 \\
\hline 61-65 & 65 & 12.50 \\
\hline$>65$ & 56 & 10.77 \\
\hline \multicolumn{3}{|l|}{ Religion } \\
\hline Hindu & 251 & 48.27 \\
\hline Muslim & 214 & 41.15 \\
\hline Others & 55 & 10.58 \\
\hline \multicolumn{3}{|l|}{ Education } \\
\hline Illiterate & 427 & 82.14 \\
\hline Primary & 74 & 14.29 \\
\hline Secondary & 19 & 3.57 \\
\hline \multicolumn{3}{|l|}{ Occupation } \\
\hline House wife & 316 & 60.77 \\
\hline Labourer & 185 & 35.58 \\
\hline Others & 19 & 3.65 \\
\hline \multicolumn{3}{|l|}{ Type of family } \\
\hline Joint & 288 & 55.38 \\
\hline Nuclear & 232 & 44.62 \\
\hline \multicolumn{3}{|l|}{ Type of House } \\
\hline Kaccha & 306 & 58.93 \\
\hline Pakka & 214 & 41.07 \\
\hline \multicolumn{3}{|c|}{ Socio-economic status } \\
\hline $\begin{array}{l}\text { Lower middle } \\
\text { class }\end{array}$ & 167 & 32.14 \\
\hline Upper lower class & 204 & 39.29 \\
\hline Lower class & 149 & 28.57 \\
\hline
\end{tabular}

Total of 520 patients were enrolled in the study. Out of 520 patients, 270 were sexually active and 250 were sexually inactive, 270, who were sexually active, 
questioned about sexual problems and coital frequency. Mean age of menopause was $47.59 \pm 3.98$ years.

Table 2: Distribution of patients according to sexual activity with duration of menopause.

\begin{tabular}{|c|c|c|c|c|}
\hline $\begin{array}{l}\text { Duration } \\
\text { of } \\
\text { menopause }\end{array}$ & $\begin{array}{l}\text { Sexually } \\
\text { active } \\
\mathrm{n}=270 \\
(51.9 \%)\end{array}$ & $\begin{array}{l}\text { Sexually } \\
\text { inactive } \\
\mathrm{n}=\mathbf{2 5 0} \\
(\mathbf{4 8 . 1 \%})\end{array}$ & $\begin{array}{l}\text { Chi- } \\
\text { square }\end{array}$ & p-value \\
\hline$\leq 5 \mathrm{yrs}$ & $\begin{array}{l}147 \\
(54.4 \%)\end{array}$ & $\begin{array}{l}43 \\
(17.2 \%)\end{array}$ & \multirow{3}{*}{140.29} & \multirow{3}{*}{$\begin{array}{l}0.0000 \\
\text { Highly } \\
\text { Significant }\end{array}$} \\
\hline $6-10 \mathrm{yrs}$ & $\begin{array}{l}108 \\
(40.0 \%)\end{array}$ & $\begin{array}{l}87 \\
(34.8 \%)\end{array}$ & & \\
\hline$\geq 11 \mathrm{yrs}$ & $\begin{array}{l}15 \\
(5.6 \%)\end{array}$ & $\begin{array}{l}120 \\
(48.0 \%)\end{array}$ & & \\
\hline
\end{tabular}

Amongst 520 patients, 195 were in the age group of 4650 years. Mean age was $55.03 \pm 6.33$ in the study population. Majority $82 \%$ were illiterates and $64.4 \%$ women were home makers and $35.6 \%$ were unskilled workers, mostly farmers. $58.9 \%$ were living in kaccha house (Table 1 ).

Table 3: Association of mean age among sexually active and sexually inactive patients.

\begin{tabular}{|lllll|} 
Category & $\begin{array}{l}\text { Sexually } \\
\text { active } \\
\text { Mean } \pm \text { SD }\end{array}$ & $\begin{array}{l}\text { Sexually } \\
\text { inactive } \\
\text { Mean } \pm \text { SD }\end{array}$ & t-test & $\begin{array}{l}\text { p- } \\
\text { value }\end{array}$ \\
\hline $\begin{array}{l}\text { Mean } \\
\text { Age }\end{array}$ & 52.42 & $62.13 \pm 6.39$ & 6.2368 & $\begin{array}{l}0.0001 \\
\text { HS }\end{array}$ \\
\hline
\end{tabular}

More than half i.e. $51.9 \%$ were sexually active among the study population. Among sexually active postmenopausal women $54.4 \%$ were sexual active, in the initial 5 years of menopause, gradually decreased $40 \%$ in duration of $6-10$ years of menopause. Only $5.6 \%$ were sexually active in 11 or more years of menopause. Among sexually inactive, majority were inactive when duration of menopause was 11 or more years. This difference was statistically significant (Table 2).

Table 4: Prevalence of sexual dysfunctions among sexually active menopausal women.

\begin{tabular}{|lcc|}
\hline $\begin{array}{l}\text { Sexual } \\
\text { symptoms }\end{array}$ & Frequency $(\mathbf{n = 2 7 0})$ & Percentage \\
\hline Vaginal dryness & 29 & 10.7 \\
\hline Dyspareunia & 29 & 10.7 \\
\hline $\begin{array}{l}\text { Decreased } \\
\text { libido }\end{array}$ & 150 & 55.6 \\
\hline
\end{tabular}

Mean age of patients was $52.42 \pm 5.23$ and $62.13 \pm 6.39$ among sexually active and sexually inactive patients, which was statistically significant (Table 3).

Prevalence of dyspareunia, vaginal dryness and decreased libido was $10.7 \%, 10.7 \%$ and $55.4 \%$ respectively among sexually active postmenopausal women (Table 4 ).
Table 5: Distribution of cases according to sexual frequency in postmenopausal women.

\begin{tabular}{|llll|}
\hline $\begin{array}{l}\text { Period } \\
\text { in } \\
\text { month }\end{array}$ & \multicolumn{4}{l}{ Sexual frequency $(\%)(\mathbf{n = 2 7 0})$} \\
\hline $\mathbf{0 - 2}$ & $122(45.19 \%)$ & $82(30.37 \%)$ & $16(5.93 \%)$ \\
\hline $\mathbf{3 - 4}$ & $16(5.93 \%)$ & $00(0.0 \%)$ & $00(0.0 \%)$ \\
\hline $\mathbf{5 - 6}$ & $34(12.59 \%)$ & $00(0.0 \%)$ & $00(0.0 \%)$ \\
\hline
\end{tabular}

About $42.9 \%$ of patients had coital frequency of 1-2 in up to 2 months. Only $6 \%$ patients had coital frequency of 5 or more times in up to 2 months (Table 5).

Table 6: Correlation of sexual dysfunctions with duration of menopause among sexually active.

\begin{tabular}{|llll|}
\hline $\begin{array}{l}\text { Duration } \\
\text { of } \\
\text { menopause } \\
\text { (in yrs) }\end{array}$ & $\begin{array}{l}\text { Vaginal } \\
\text { dryness } \\
(\mathbf{n}=29)\end{array}$ & $\begin{array}{l}\text { Dyspareunia } \\
(\mathbf{n}=29)\end{array}$ & $\begin{array}{l}\text { Decreased } \\
\text { libido } \\
(\mathbf{n}=150)\end{array}$ \\
\hline$\leq \mathbf{5}(\mathbf{n}=\mathbf{1 4 7})$ & $11(7.5 \%)$ & $15(10.2 \%)$ & $69(47.0 \%)$ \\
\hline $\begin{array}{l}\mathbf{6 - 1 0} \\
(\mathbf{n}=\mathbf{1 0 8})\end{array}$ & 14 & $14(12.9 \%)$ & $70(64.8 \%)$ \\
\hline $\mathbf{1 1}(\mathbf{n = 1 5})$ & $\begin{array}{l}(13.0 \%) \\
(26.7 \%)\end{array}$ & $0(0 \%)$ & $11(73.3 \%)$ \\
\hline
\end{tabular}

Sexual dysfunction increased as the duration of menopause increased (Table 6).

\section{DISCUSSION}

The present study revealed that, the mean age of menopause was $47.59 \pm 3.98$ in rural India which corresponds to other studies. ${ }^{11-14}$ In our study, $51.9 \%$ of women were sexually active which were comparable to the study of $58.6 \%, 51 \%, 52 \%$ and $40 \%$ sexually active in shah et $\mathrm{al}^{15}$, Nappi RE et $\mathrm{al}^{16}$, Jennifer $\mathrm{S}$ et $\mathrm{al}^{17}$ and Versi E et al $^{18}$ studies respectively.

Although we did not evaluate the various reasons for sexual inactivity, we learned the myths and misconception that sex is only for procreation. Selfdeclaration from one and both the parties to stop sexual intimacy once their child gets married. Lack of privacy, lack of place; fear that if caught in sexual act leads to sexual inactivity.

Our study revealed that sexual activity decreases from $54 \%$ to $5.6 \%$ as the duration of menopause increases which were comparable to the other studies. ${ }^{19-21}$ Long standing undiagnosed and untreated sexual problems might be one of the reasons to stop sexual activity. This stresses the need of early identification and treatment of sexual problems among postmenopausal women.

Estimates of point prevalence of post-menopausal dyspareunia derived from large scale studies range from $2 \%-29 \%$. Recent studies have obtained higher prevalence 
estimates than older investigation, which may be; in part a changing attitude about sexual functioning in aging population. For example, some studies only questioned sexually active women about sexual difficulty or pain during intercourse. As such they may have under represented their findings because many women do not engage in sexual activity as it is painful. On the other hand the difference may, at least in part, reflect sociocultural, life style, biological and variation of reporting methods among different populations. $^{22}$ Prevalence of dyspareunia is $10 \%$ as mentioned in clinical guidelines. ${ }^{23}$ The findings of our study showed that dyspareunia was seen in $10.7 \%$ of the patients comparable to $11 \%$ in Ballinger SE study. ${ }^{24}$

Discussions regarding female dysfunction in postmenopausal women have not been a routine part of our health care, hence magnitude of female sexual dysfunction are poorly understood.

The current study showed that vaginal dryness was seen in $10.7 \%$ of patients. This study is in line with Sugdeo $\mathrm{MM}$ et al and GKP et al study, which showed that $8.8 \%$ and $10.8 \%$ in rural patients are affected with vaginal dryness respectively. ${ }^{25,26}$ Our study was also comparable to a population based cross sectional study by Williams et al, which revealed that of $7.3 \%$ vaginal dryness. The study was not in line with Cognacc A et al which showed high prevalence of $62 \%-67 \%$ of vaginal dryness. ${ }^{27,28}$ This is because the prevailing cultural beliefs in our country might discourage and inhibit the older individuals to consult a doctor and discuss about their sexual life leading to under reporting of the prevalence.

Another aspect worth mentioning that loss of libido was seen in $55.4 \%$ of the postmenopausal women which were comparable $59 \%$ and $43 \%$ in study by Rita et al and Stacy et al respectively. ${ }^{12,21}$ This finding was not correlating to $81.5 \%$ in the study of Bansal et al and $90.8 \%$ in tne study of Dasgupta et al. ${ }^{29}$ This difference could be because even sexually inactive menopausal women were included in the study.

In our study, majority of patients had coital frequency of 1-2 in two months correlates to study of Banoroft et al. ${ }^{30}$ Shabnam et al also found significant relationship between sexual desire and number of sexual intercourse. Holly $M$ et al also found half of women reported sexual intercourse once or twice a month, while other half atleast once a week. ${ }^{31,32}$

In our study, sexual dysfunction among sexually active menopausal women increased as the duration of menopause increased, which was not statistically significant, but was comparable to the study of Addis et al and Hayes RD et al. ${ }^{33,34}$

A study in Australia revealed all types of sexual dysfunction increased significantly with age and apart from age sexual dysfunction increased with advancing menopausal years. ${ }^{35}$

But there was lack of awareness of cause and management pertaining to sexual dysfunctions. A wide gap in the knowledge has been documented in women from rural area in developing country. Only $2.1 \%$ of the patients were willing to take some treatment for it. The current study had some limitations as socio demographic characters were not compared with sexual dyfunctions as in the study by Sathyanarayana TS et al showed that employed and nuclear family were more sexually active. $^{19}$

\section{CONCLUSION}

Taking into the consideration of endocrine and age specific changes, postmenopausal women face sexual dysfunction. Physicians should provide them with the opportunity to express their thoughts, offering them alternatives for both evaluation and treatments. It is mandatory to increase recognition and perceptions of female sexual dysfunction and dismiss taboo and improper thoughts which will help in the better management of patients allowing them to lead good quality of life.

\section{ACKNOWLEDGEMENTS}

We express our deep sense of gratitude to the Management, JIIU Trust and Dr. Amarnath B. Solepure, Dean, IIMSR Medical College, Badnapur, Jalna, Maharashtra. We also acknowledge the help and support of Dr. A. M. Khadri, Medical Superintendent, Noor Hospital, Badnapur and Mr. Pankaj R. Gangwal, Statistician, Department of Community Medicine of IIMSR Medical College, Badnapur, Jalna during data collection.

\section{Funding: No funding sources}

Conflict of interest: None declared

Ethical approval: The study was approved by the Institutional Ethics Committee

\section{REFERENCES}

1. World Health Organization 2006, Life Table for WHO member states available at: http:// www. int/ whois/ database/ life-tables/life-tables.cfm.

2. Hatzimouratidis K, Hatzichristou D. Sexual Dysfunction: classification and definition. J Sex Med. 2007;4:241-50.

3. Diokno AC, Brown MB. Herzog AR, Sexual function in the elderly. Arch Inters Med. 1990;150:197-200.

4. Nappi RE. Lachowsky M. Mewnopause and sexuality: prevalence of symptoms and impact on quality of life. Maturitas. 2009;63:138-141.

5. Pettersson K. Gustftsson JA. Role of estrogen receptor in the estrogen action. Annu Rev Physio. 2001;63:165192. 
6. Hodgins-MB spike RC Mackie RM Maclean B. An immune histo chemical study of androgen, estrogen and progesterone, receptors in the valve and vagina. $\mathrm{Br} \mathrm{J}$ Obstet Gynaccol. 1998;105:216-22.

7. Orkun T, Karen B. Management of Vulvovaginal Atrophy-related Sexual Dysfunction in postmenopausal women. Menopause. 2012;19(1):109-17.

8. Mostafa RM, Nasserallah YS. Female sexual dysfunction among menopausal women. Human Andrology. 2015;8:121-3.

9. Goel N. Pnndiya Gupta Menopause. 1st edition page132-133.

10. Kingsberg SA, Simon JA, Goldslan I. The current outlook for testosterone in the management of hypoactive sexual desire disorder in postmonopausal women. J Sex M D. 2008;5(Sappl4):182-3.

11. Bansal P, Choudhary A. Menopausal problems among rural middle aged women of Punjab. Int Journal of Research in Health science. 2013;1(3):103-9.

12. Aaron R, Muliyil J. A cross sectional study from rural south India. Natl Med J India. 2002;15:14-7.

13. Palacios S, Hendrson VW, Siseles N, Tan D, Villaseca P. Age of menopause and impact of climacteric symptoms by geographical region. Climacteric 2010;13(5):419-28.

14. Kakkar V, Kaur D. Assessment of the variation in menopausal symptoms with age, education and working/non-working status in north-Indian sub population using menopause raty scale (MRS). Maturitas. 2007;57(3):306-14.

15. Shah R, Chitlangs SL, Iddya U, Balaiah D. Menopausal symptoms in urban Indian women. Indian Journal of OBS and Gynac today. 2004;11(10):667-70.

16. Nappi RE, Palacios S, Panay N, Particco M, Krychman ML. Vulvar and vaginal atrophy in four European countries: evidence from the European REVIVE survey. Climacteric. 2016;19(2):188-97.

17. Jeennifers, Mc Call-Hosenfeld, Sarah A. Jaramillo MS et al. Correlates of sexual satisfaction among sexually active post menopausal women in the women's health initiative- observational study. J Gen Inter Med. 2008;23(12):200-9.

18. Versi E, Harvey MA, Cardozol, Brincat M, stud JW. Urogenital prolapse and atrophy at Menopause: A prevalence study. Int Uro Gynecol J Pelvic floor dysfunction. 2001;12:107-10.

19. Rao S, Ismail S. Sexual disorders among elderly: an epidemiological study in south Indian rural population. Indian J Psychiatry. 2015;57(3):236-41.

20. Diokno AC, Brown MB. Sexual function in the elderly. Arch Intern Med. 1990;150(1):197-200.
21. Lindau ST, Schumm P. A study of sexuality and health among older adults in the United States. N Engl J Med. 2007;357:762-74

22. Kao A, Binik YM. Dyspareunia in postmenopausal women:A Critical review.Pain Res Mang. 2008;13(3):243-54.

23. Digumarti L, Agrawal N. Clinical practice guidelines on menopause: An executive summary and recommendation. J Midlife Health. 2013;4(2):77-106.

24. Ballinger SE. Psychosocial stress and symptoms of menopause: A comparative study of menopause clinic patients and non-patients. Maturitas. 1985;7:315-27.

25. Sugdeo MM. Dimple Arora. Menopausal symptoms: A comparative study in rural and urban women. JK Science 2011;13(1):37-41.

26. Arouna S, Salame B. The quality of life during and after menopause among rural women $\mathrm{J}$ clin Diagn Res. 2013;7(1):135-9.

27. Williams RE, Kalilani L, Di Benedetti DB. Zhoce X, Fennel SE, Clark RV. Health care seeking and treatment for menopausal symptoms in the nited states. Maturitas. 2007;58(4):348-58.

28. Cognacc A, Carbone MM, Palma F. AGATA study, prevalena and association between objective signs and subjective symptoms of vaginal atrophy:the AGATA study. Menopause. 2016;37-39.

29. Doyel D, Subha R. Menopausal problems among rural and urban women from eastern India. Journal of Social, Behavioral And Health Science. 2009;13(1):20-33.

30. Banoroft J. The endourinology of sexual arousal. J Endocrinol. 2005;186:411-27.

31. Bakouie F, Amiri FN. Sexual functions among married menopausal women in Amol (Iran). J Midlife Health. 2011;2(2):77-80.

32. Holly M. Thomas, Cindy L. Bryce, Roberta B. Ness and Rachel Hess. Dyspareunia is assosciated with decreased frequency of intercourse in the menopausal transition. Menopause. 2011;18(2):152-157.

33. Addis B. Van Den Eedensle. Wassel- Fyr CL, Vittinghoff E. Broun J. Thom DH, Reproductive risk factors for incontinence study at Kaiss study group. Sexual activity and function in middle-aged and older women. Obstet Gynecol. 2006;107:755-764.

34. Hayes RD, Dennerstein L, Bennett CM, Koochaki PE, Leiblum SR, Graziottin A. Relationship between hypoactive sexual desire and aging. Fertil Steril. 2007;87:107-12.

35. Dennerstein L, Alaxander JL, Kotz K. The menopause and sexual functioning: A review of population based studies. Annu Rev Sex Res. 2003;14:64-82.

Cite this article as: Santpure AS, Nagapurkar SN, Giri PA, Bhanap PL. Female sexual dysfunction amongst rural postmenopausal woman. Int J Reprod Contracept Obstet Gynecol 2016;5:4385-9. 